\title{
EVOLUTION OF LAW ON ANTICIPATORY BAIL IN INDIA
}

MALIKA SHAH

mgshah@jgu.edu.in

Lecturer at Jindal Global Law School, O.P. Jindal Global University, Sonipat (India)

VAIBHAV CHADHA

vchadha@jgu.edu.in

Lecturer at Jindal Global Law School, O.P. Jindal Global University, Sonipat (India)

\section{Abstract}

Sushila Aggarwal $v$ State (NCT of Delhi) forms an important part of the law on anticipatory Bail in India. Prior to Sushila Aggarwal judgment, the law on anticipatory bail in India was ambiguous due to the varying interpretations of section 438 of the Criminal Procedure Code 1973 (anticipatory bail) by the Supreme Court. It was only in the year 2020 that the law on the matter was settled by the Supreme Court in its Sushila Aggarwal judgment.

With this paper, the authors aim to trace the evolution of the law on anticipatory bail in India. It focusses on the landmark judgments of the Supreme Court and meanders its way through conflicting opinions of the Court. The paper concludes by welcoming the Sushila Aggarwal judgment for settling the long ambiguous law on anticipatory bail in India. However, it also highlights the concerns that Constitution Bench failed to appreciate, which if addressed would have made the law free of the loopholes presently plaguing the law on anticipatory bail.

\section{Keywords}

Sushila Aggarwal v State (NCT of Delhi), Gurbaksh Singh Sibbia v State of Punjab, Section 438 Code of Criminal Procedure 1973, Anticipatory Bail and Bail

\section{How to cite this article}

Shah, Malika; Chadha, Vaibhav (2021). Evolution of Law on Anticipatory Bail in India. Janus.net, e-journal of international relations. Vol12, No. 1, May-October 2021. Consulted [online] at date oflast visit, https://doi.org/10.26619/1647-7251.12.1.14

Article received on July 24, 2020 and accepted for publication on February 27, 2021

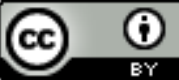




\section{EVOLUTION OF LAW ON ANTICIPATORY BAIL IN INDIA}

MALIKA SHAH

VAIBHAV CHADHA

\section{Introduction}

One of the important aims of arresting and detaining the accused person is to ensure his presence at the time of trial and to make sure that he is present to receive his sentence, if convicted ${ }^{1}$. This purpose can, however, also be attained through the system of Bail. Bail means " $[T]$ o procure the release of a person from legal custody, by undertaking that he shall appear at the time and place designated and submit himself to the jurisdiction and judgment of the court"2.

The Code of Criminal Procedure 1973 (hereinafter CrPC) does not define the term "bail", however, it defines the terms "bailable offence" and "non-bailable offence." "Bailable offence" has been defined under sec 2(a) of the CrPC as an offence that is shown in the First Schedule as bailable, or which has been made bailable by any other law effective for the time being while "non bailable offence" has been defined as any other offence. Whether any offence is bailable or not, no test or criterion has been laid down for determining it. It is dependent on the fact whether in the First schedule it has been shown as bailable or non-bailable ${ }^{3}$.

\section{Development of the law on Anticipatory Bail in India}

Prior to the Code of 1973 , there was no provision related to anticipatory bail in the earlier Code of Criminal Procedure 1898. The prevalent position prior to 1973 was that the courts did not have the authority to grant anticipatory bail ${ }^{4}$.

In Amir Chand $v$ Crown, the Court stated that a person who was not under any kind of restriction could be put under restriction by granting bail. The Court further explained that there was no provision in the Code of 1898 under which "anticipatory bail" could be granted $^{5}$. Similarly, in Jubar Mal $v$ State, Rajasthan High Court observed that under the Code of Criminal Procedure 1898, neither the High Court nor the subordinate courts had the power to grant bail to a person if that person had not been arrested or detained in

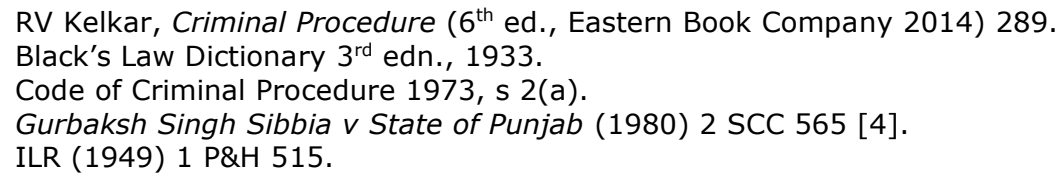


custody or brought before the court or no warrant of arrest or any order in writing for his arrest had been issued against him ${ }^{6}$. The Court in State of Madhya Pradesh $v$ Narayan Prasad Jaiswal observed that exercising such a power would be a deviation for the court. By placing reliance on a Privy Council case of King Emperor $v$ Khwaja Nazir Ahmad ${ }^{7}$, the Court stated that following such a practice would amount to influencing the matters that are within the territory of the Police ${ }^{8}$. Eventually, the court in State of Madhya Pradesh $v$ Narayan Prasad Jaiswal concluded that under the provisions of the Code of 1898, bail could not be granted to a person who hadn't been arrested for any charge of a crime ${ }^{9}$.

The need for introduction of a new provision in the CrPC authorizing High Court and Court of Session to grant "anticipatory bail" was pointed out by the $41^{\text {st }}$ Law Commission of India in its report in the year 1969. In para 39.9 of volume I, the Commission observed that there was a need for granting anticipatory bail because there was a possibility that powerful persons may try to implicate their rivals in fake cases with the motive of "disgracing" them or with the motive of getting them to undergo imprisonment for few days. The Report also observed that this practice had increased with an accentuation of political rivalry. It was also felt that there was no basis to require a person accused of an offence to submit to custody, stay in prison and apply for bail in cases where there were sufficient reasons for holding that the accused person was not likely to misuse his liberty on bail and abscond. The Law Commission recommended conferring this power only to the High Court and Court of Session and it also stated that such order would come into force at the time of arrest or subsequently. The Commission observed its inability to exhaustively lay down the conditions under which anticipatory bail could be granted and left it to the discretion of the court. However, it clarified that while granting anticipatory bail, no such observation that was likely to prejudice fair trial ought to be made ${ }^{10}$.

The Central Government accepted the recommendations of the Law Commission and introduced clause 447 in the Draft Bill of the Code of Criminal Procedure 1970 with the intent of conferring authority on the High Court and Court of Session to grant anticipatory bail ${ }^{11}$. The Law Commission of India in its $48^{\text {th }}$ Report (1972), in para 31, observed that a provision for grant of anticipatory bail introduced by the Bill was in line with the suggestions made by the $41^{\text {st }}$ Law Commission. While agreeing with the provision, the Commission observed that such a power was required to be exercised in exceptional cases alone. It further clarified that in order to prevent the misuse of the provision by dishonest petitioners, the final order granting anticipatory bail ought to be made only after giving notice to the Public Prosecutor and the initial order ought to be a temporary one. The Commission further observed that the provision must clearly state that such an order could only be passed after recording reasons and if the court was convinced that such a direction was necessary in the "interests of justice"12. With some modifications, clause 447 of the Draft Bill Code of 1970 finally became section 438 of the CrPC 1973.

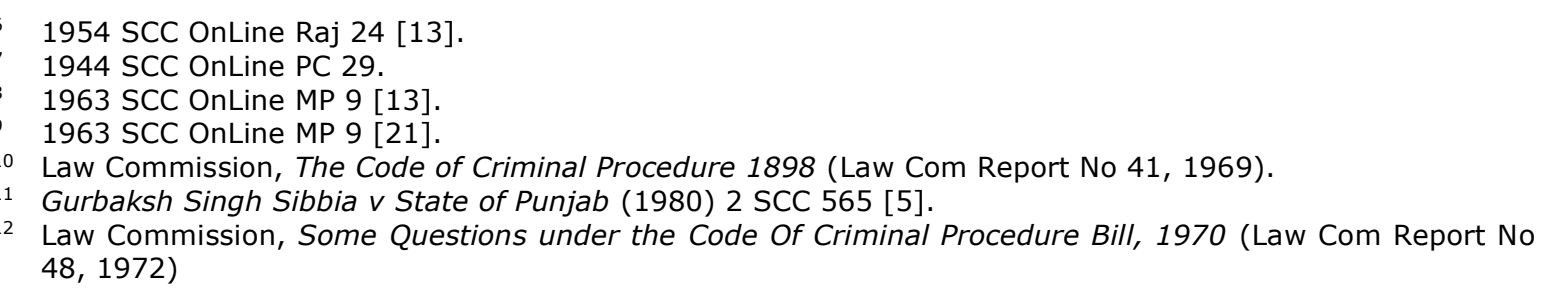




\section{Initial attempts to determine the scope of anticipatory bail}

In Balchand Jain $v$ State of MP, Bhagwati, J., when discussing the scope of section 438, observed that the section deals with the issue of "anticipatory bail" though the word "anticipatory bail" has not been mentioned in the section itself. According to him "Anticipatory bail" was a misnomer. When the court grants "anticipatory bail", it makes an order that in case a person is arrested, he shall be enlarged on bail. The question of release on bail does not arise unless a person is arrested and it is only when the person is arrested that the order granting "anticipatory bail" becomes effective ${ }^{13}$.

The Constitutional Bench of the Supreme Court of India delivered its landmark judgment on the issue of anticipatory bail in Gurbaksh Singh Sibbia $v$ State of Punjab ${ }^{14}$. The matter reached the Supreme Court (SC) in an appeal against the judgment of the Full Bench of the High Court of Punjab and Haryana. The matter involved an anticipatory bail application of the then Minister of Irrigation and Power of the government of Punjab against whom allegations of political corruption were made.

The High Court of Punjab and Haryana imposed certain limitations on the exercise of powers under Section 438 of the Code. The High Court held that the powers under section 438 ought not to be exercised in serious cases, including certain categories of economic offences, or offences punishable with death or imprisonment for life. The Court also read into section 438 the limitations imposed under section 437 and discouraged exercising such powers in cases where the accused was required under section 167(2) of the CrPC or section 27 of the Indian Evidence Act 1872. Further, the Court ruled that the power should be exercised sparingly and in exceptional cases alone. There could be no grant of blanket anticipatory bail order and the court, before granting an anticipatory bail order under section 438, must satisfy itself that any allegations of malafide in the petition were substantial and the accusations appeared false and groundless ${ }^{15}$.

The SC at the very beginning made a distinction between regular bail and anticipatory bail. The SC observed that in contrast to post-arrest order of bail, anticipatory bail was a pre-arrest legal procedure. It dictates that a person in whose favour an order of anticipatory bail is granted for a specific offence is subsequently arrested on the allegations for that offence, such a person shall be released on bail ${ }^{16}$. The SC overruled the judgement of the High Court and disallowed imposition of limitations on section 438 . The Court observed that it cannot impose limitations not intended by the legislature especially in a case involving a right as valuable as the fundamental right to life and personal liberty. The Court further discussed sections 437 and 439 of the CrPC 1973 and also how the legislature was not working on a clean slate while drafting section 438 . The Court observed that the legislature could have imposed similar conditions under section 438 if it wanted to. The SC relied on the 41st Law Commission Report wherein para 39.9 recommended complete discretion to be given to the superior courts that were expected to exercise it judiciously. Moreover, according to the Law Commission Report, enumeration of such conditions would be a difficult task as each case needed to be dealt with individually. The court also made it clear that these observations would not mean

3 Balchand Jain $v$ State of M.P. (1976) 4 SCC 572 [2].

(1980) 2 SCC 565

5 (1980) 2 SCC 565, 576-577.

16 (1980) 2 SCC 565 [7]. 
that anticipatory bail would be granted without imposing any condition and that the same would be contrary to the terms of section 438 itself $^{17}$.

With respect to the High Court's view that anticipatory bail ought not to be granted in case of offences involving death penalty or imprisonment for life or certain kinds of economic offences, the SC observed that the legislature had only mentioned the words "non-bailable" in section 438 without putting qualifications on the same and hence, it would not be right on the part of the Court to read in conditions laid down under section $437(1)$ in section $438^{18}$. Further, the SC held that the High Court's ruling for not granting anticipatory bail where the accused was required under section 27 of the Evidence Act 1872, holds no ground since section 438 itself allows imposition of conditions ensuring cooperation on the part of the accused for the purpose of Police investigation. The SC also stated that the court could also impose conditions as it deemed fit in the relevant case and in the interest of justice ${ }^{19}$.

Regarding the High Court's observation that a "special case" needs to be made out for the operation of section 438, the SC held that though a case needed to be made out for the exercise of such power by the Court, there was nothing in the section which required a "special case" to be made out for the same. Similarly, the SC overruled that the power needed to be exercised in exceptional cases alone. Taking support from already decided case laws ${ }^{20}$, the Supreme Court held that the judicious exercise of powers by the concerned courts would take care of the evil consequences that might find itself attached to such an exercise of power ${ }^{21}$.

The SC eventually overruled the judgement of the High Court of Punjab and Haryana on most points, barring its observation on granting a blanket anticipatory bail order ${ }^{22}$ and refusing to read into section 438 any conditions and limitation not intended by the legislature, leaving matters at the discretion of the High Court and Court of Sessions.

\section{Inconsistency in subsequent judgments}

The Supreme Court in Salauddin Abdulsamad Shaikh $v$ State of Maharashtra ${ }^{23}$ deviated from the Supreme Court's judgment in Sibbia case on the point of time limit for the operation of anticipatory bail. In Salauddin case, the Court held that since anticipatory bail is granted during the pendency of investigation when the Court is not informed about the nature of evidence against the accused, it should be limited in time. Once this limited period expires, it should be left to the regular courts to deal with the matter of bail based on the evidence before them ${ }^{24}$.

As per Sibbia case, an order for anticipatory bail would normally continue till the end of the trial. However, the SC in the Salauddin case categorically stated that it is important to put down a time limit on the same for regular courts to deal with the matter. Subsequently, the decision in the Salauddin case was followed in a number of other cases

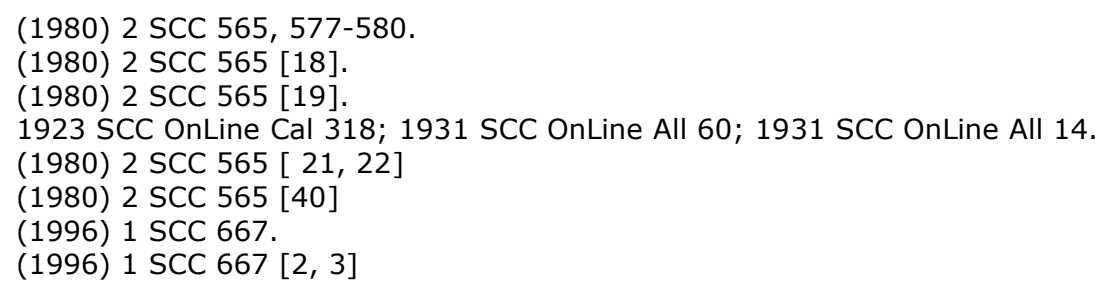


such as K.L. Verma $v$ State ${ }^{25}$, Sunita Devi v State of Bihar ${ }^{26}$, Nirmal Jeet Kaur $v$ State of $M P^{27}$ and HDFC Bank Limited $v$ J.J. Mannan ${ }^{28}$.

In the HDFC Bank Limited case, the SC followed the reasoning given in Salauddin case to the extent that anticipatory bail ought to be given for a limited period to allow the accused to surrender and obtain regular bail ${ }^{29}$. Though the Court recognised the need for anticipatory bail in order to prevent humiliation of a person from arrest arising out of the personal vendetta of the complainant, at the same time the Court also held that the provision cannot be used as an excuse not to surrender before the court once the investigation has been completed and charge sheet has been filed. It would amount to a violation of section 438 itself $^{30}$. The SC further observed that the purpose of the provision was to provide a mechanism for the accused to be released on bail during investigation and no further. Once the investigation was complete and the charge sheet was filed, the use of section 438 ends and the accused needs to submit himself before the Court and seek ordinary bail. The Court observed that anticipatory bail cannot provide a cover to the accused to avoid appearance before the trial court ${ }^{31}$.

The chain of judgments following reasoning of the Salauddin case was finally interrupted in the SS Mhetre $v$ State of Maharashtra ${ }^{32}$ wherein the SC held that the later smaller bench judgments (less than 5 judges) on the issue were not in consonance with the SC Constitution Bench decision in the Sibbia case and hence, stood per incuriam. The Court finally decided to follow the Constitution Bench decision of Sibbia. In this case, the SC held that section 438 though extraordinary, is not to be invoked in exceptional cases alone $^{33}$. Grant or refusal of bail is entirely discretionary, and the Court is at liberty and fully justified to impose conditions while granting anticipatory bail under section $438^{34}$. The court refused to read into section 438 any condition not expressly provided thereunder ${ }^{35}$. The Court further observed that once anticipatory bail was granted, it should ordinarily continue till the end of the trial ${ }^{36}$ and once the accused was released on anticipatory bail, it would be unreasonable to compel the accused to surrender before the trial court and again apply for regular bail ${ }^{37}$. The Court also held that the life of the order granting bail under section 438 cannot be curtailed ${ }^{38}$, though the Court has a right to cancel it ${ }^{39}$.

Later judgment in Bhadresh Bipinbhai Sheth $v$ State of Gujarat ${ }^{40}$ supported the view followed in Sibbia and Mhetre. However, the Court departed from the view taken in the Salauddin case in Satpal Singh $v$ State of Punjab ${ }^{41}$, leaving the law on anticipatory bail under section 438 ambiguous and uncertain. In the Satpal Singh case, the SC held that

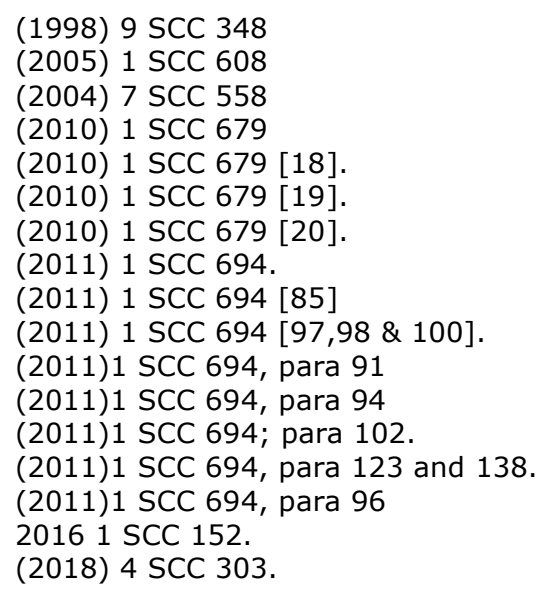


anticipatory bail under section 438 remains operational only till the court summons the accused based on the charge sheet after which the accused has to proceed under section 439 for regular bail, which needs to be considered by the Court on merits. Thus, the Court limited the life of an order of anticipatory bail under section $438^{42}$. It was finally in Sushila Aggarwal $v$ State (NCT of Delhi), where the ambiguity over the law of anticipatory bail was finally settled ${ }^{43}$.

\section{Sushila Aggarwal v State (NCT of Delhi): The law and its unattended corners}

Eventually, the SC in Sushila Aggarwal $v$ State (NCT of Delhi), laid to rest the ambiguity over the law of anticipatory bail in India ${ }^{44}$. In view of the conflicting opinions of the different SC Benches of varying strength, the Court framed two important questions that required to be answered to settled the law on the issue. The first question was "Whether the protection granted to a person under Section 438 of the CrPC should be limited to a fixed period so as to enable the person to surrender before the Trial Court and seek regular bail?" The second question was, "Whether the life of an anticipatory bail should end at the time and stage when the accused is summoned to the court?"45.

As far as the first question was concerned, the five-judge bench of the SC held that the protection under section 438 need not always be granted for a limited period of time and had to be granted in favour of the accused without any time restriction. Normal restrictions under section 437(3) read with section 438(2) ought not to be imposed unless the specificity of the case required imposition of special conditions ${ }^{46}$.

With respect to the second question, the court held that the life of an anticipatory bail order would not normally end when the accused is summoned by the Court or when charges are framed against him and it would normally continue till the end of the trial. Ordinarily anticipatory bail would continue after the filing of the charge sheet till the end of the trial ${ }^{47}$. However, it also recognised the Court's discretion to limit the tenure based on the peculiarity or specificity of the concerned case ${ }^{48}$.

With this judgment, the SC explicitly overruled Salauddin; K.L. Verma and other judgments which held the view that tenure of an anticipatory bail order ought to be limited. The SC also overruled Mhetre as far as it put a bar on the imposition of any restrictive condition in an order for anticipatory bail ${ }^{49}$. In the present case, the SC extensively made reference to and followed its decision in Sibbia. The Court did not deem it proper to narrow down the powers of the High Court and Court of Session with respect to the tenure of an anticipatory bail ${ }^{50}$.

It is remarkable to note that the 41st Law Commission of India in its report laid down the purpose and need for including section 438 in the Code. According to the report, the

\footnotetext{
(2018) 4 SCC 303.

Sushila Aggarwal $v$ State (NCT of Delhi) SLP (Crl.) Nos. 7281-7282/2017.

Sushila Aggarwal v State (NCT of Delhi) SLP (Crl.) Nos. 7281-7282/2017.

Sushila Aggarwal v State (NCT of Delhi) SLP (Crl.) Nos. 7281-7282/2017, p. 2.

Sushila Aggarwal v State (NCT of Delhi) SLP (Crl.) Nos. 7281-7282/2017, p. 127 [1(1)].

Sushila Aggarwal $v$ State (NCT of Delhi) SLP (Crl.) Nos. 7281-7282/2017, p. 130 [1(5)]

Sushila Aggarwal v State (NCT of Delhi) SLP (Crl.) Nos. 7281-7282/2017, p. 128 [1(2)].

Sushila Aggarwal $v$ State (NCT of Delhi) SLP (Crl.) Nos. 7281-7282/2017, p. 132 [1(12)].

Sushila Aggarwal v State (NCT of Delhi) SLP (Crl.) Nos. 7281-7282/2017, p. 120(c).
} 
basic purpose of the provision of anticipatory bail was to prevent false implication of the person and his consequent humiliation ${ }^{51}$. This purpose has also been reiterated in several judgments of the SC. In Bharat Chaudhary $v$ State of Bihar, the court stated that the purpose of section 438 was to "prevent undue harassment of the accused persons by pre-trial arrest and detention" ${ }^{\prime 52}$. Later, in Satpal Singh $v$ State of Punjab, the Court held that the object of section 438 was to afford protection pending investigation, after which the accused needs to seek regular bail after submission of the charge sheet from the court where the entire material was placed ${ }^{53}$. Section 438 , thus, contemplates arrest at the stage of investigation and affords a protective mechanism against arrest during the investigation process. The purpose is not to allow the accused to evade their appearance before the trial court on the pretext of anticipatory bail.

The basic purpose of section 438, as enumerated above, could have been best met if the duration of anticipatory bail was limited to a certain period of time rather than extending it till the end of the trial. By limiting the operation of anticipatory bail, the Court of Session or High Court would have prevented the arrest and associated humiliation of the applicant till the stage investigation would have somewhat reached a conclusive end. At the same time, placing such limitation would also have allowed regular courts, who were to be presented with the matter, to judiciously appreciate the need for bail based on the facts and circumstances of the case that the court granting anticipatory bail would not be fully aware of.

Thus, limiting the period of anticipatory bail in the suggested manner would serve the dual purpose of saving the applicant from undue humiliation associated with arrest, and at the same time allowing the regular courts to decide on the necessity of arrest or bail based on the facts and circumstances of the case presented before it. This view also finds support from the argument made by the Additional Solicitor General of India (ASG), Vikramjit Banerjee, who was correct in stating that the purpose of section 438 is to afford protection during investigation alone and the accused is to apply for regular bail from the concerned court once the charge sheet has been filed ${ }^{54}$. In this regard, the decision of the SC in K.L. Verma seems relevant. The Court in K.L. Verma observed that the limit for an anticipatory bail should be guided by the facts of the case allowing the accused reasonable time to apply for regular bail. According to the judgment, anticipatory bail would continue till the regular bail application is disposed of one way or the other, thereby protecting the purpose of anticipatory bail under section $438^{55}$. Keeping in view the basic purpose of section 438, Salauddi, K.L.Verma and similar judgments on the tenure of anticipatory bail seem more appropriate and legally sound.

An order of anticipatory bail till the end of the trial has several drawbacks. The most significant drawback is its ill-effect on the provisions of regular bail set out under section 437 and 439 of the CrPC. Putting no limit on the order granting anticipatory bail could render the provisions related to bail under sections 437 and $439 \mathrm{CrPC}$ redundant, by allowing the accused to bypass regular courts. In K.L. Verma $v$ State, the court while restricting the application of anticipatory bail in cases involving apprehension of arrest in

51 Law Commission, The Code of Criminal Procedure 1898 (Law Com Report No 41, 1969), para 39.9.

52 (2003) 8 SCC 77, para 7.

3 (2018) 13 SCC 813, para 13.

54 Sushila Aggarwal v State (NCT of Delhi) SLP (Crl.) Nos. 7281-7282/2017, p. 23 [5].

55 (1998) 9 SCC 348 [3]. 
non-bailable cases, rightly observed that an anticipatory bail order cannot be used as a means to bypass regular courts meant to try the offender ${ }^{56}$.

Allowing anticipatory bail till the end of the trial also renders otiose section 209(b) CrPC. In a case exclusively triable by a Court of Sessions, section 209(b) CrPC empowers the Magistrate to remand the accused to custody during or till the conclusion of trial. In Uday Mohanlal Acharya $v$ State of Maharashtra, the court held that even if the accused is found to be on bail, the committing Magistrate has the power to cancel such bail if considered necessary ${ }^{57}$. The operation of section 209(b) becomes difficult if we follow the interpretation of section 438 as defined in the Sushila Aggarwal case. According to the Sushila Aggarwal case, firstly, an anticipatory bail needs to be ordinarily extended till the end of the trial. Secondly, it can only be cancelled by the Court granting such a bail, i.e. Court of Sessions or High Court ${ }^{58}$. The cumulative effect of both these observations make section 209(b) otiose since it takes away the power from the Magistrate to cancel the bail and commit the accused to custody. This concern was also raised by ASG Vikramjit Banerjee before the court in the Sushila Aggarwal case but was left unredressed ${ }^{59}$. This problem could have been easily avoided by the Court had it followed its decision in the K.L Verma case. According to the judgment, the Court held that the operation of anticipatory bail shall continue till the disposal of the accused's application for regular bail and no further. This decision does not terminate the protection granted to the accused under section 438 as soon as he/she applies for regular bail. However, such protection comes to an end when a decision has been taken on the application of the accused for a regular bail ${ }^{60}$.

Section 438 must not be interpreted in a manner that defeats the purpose of other provisions in the Code. The SC in Reserve Bank of India $v$ Peerless General Finance and Investment Co. Ltd rightly observed:

"Interpretation must depend on the text and the context...One may well say if the text is the texture, context is what gives the colour. Neither can be ignored. Both are important... With these glasses we must look at the Act as a whole and discover what each section, each clause, each phrase and each word is meant and designed to say as to fit into the scheme of the entire Act. No part of a statute and no word of a statute can be construed in isolation. Statutes have to be construed so that every word has a place and everything is in its place." 61

The court, by not limiting the period for anticipatory bail, has also failed to draw a distinction between anticipatory bail under section 438 and regular bail under sections 437 and $439^{62}$. The anticipatory bail application must put forth basic facts that showcase why the applicant apprehends arrest. These are necessary for the court to assess the "threat or apprehension, its gravity or seriousness, and the appropriateness of any

\footnotetext{
56 (1998) 9 SCC 348 [3].

57 (2001) 5 SCC 453, para 5.

58 Sushila Aggarwal v State (NCT of Delhi) SLP (Crl.) Nos. 7281-7282/2017, p. 131 [1(9)].

59 Sushila Aggarwal v State (NCT of Delhi) SLP (Crl.) Nos. 7281-7282/2017, p. 24 [5.1].

${ }^{60}$ (1998) 9 SCC 348 [3].

61 (1987) 1 SCC 424, p. 450 [33].

62 Sushila Aggarwal v State (NCT of Delhi) SLP (Crl.) Nos. 7281-7282/2017, p. 13 [3].
} 
condition that may have to be imposed"63. Anticipatory Bail is granted at a nascent stage where there is not enough material placed before the court regarding the involvement of the accused in the commission of the offence and solely depends on the threat or apprehension of arrest ${ }^{64}$. The investigating agency cannot be expected to prove the guilt of the accused applicant at the stage of such application. ${ }^{65}$ Therefore, the question of anticipatory bail arises at a rudimentary stage of the investigation process and thus, it cannot be compared with a regular bail.

Further, in the Sushila Aggarwal case, the SC negated the concerns raised over impediments which such prolonged anticipatory bail order would put on the investigating agency. In Sushila Aggarwal, the SC referred to "limited custody" or "deemed custody" as mentioned in Sibbia case. In Sibbia case, the court invoked the principle mentioned by the SC in the case State of UP v Deoman Upadhyay ${ }^{66}$. The SC observed that when the need arose, the prosecution could claim the advantage of section 27 of the Indian Evidence Act 1872 with respect to discovery of facts made in pursuance of information provided by a person who was released on bail ${ }^{67}$.

On this point, the SC failed to appreciate the purpose and importance of investigation. Anticipatory bail at the very threshold may interfere with the investigation process in a case. The entire purpose of section $167 \mathrm{CrPC}$ is to afford an opportunity to the investigating agency to interrogate the accused person in isolation and extract incriminating evidence from him. Despite certain limitations provided under section 438 (2) of the CrPC that allow the accused to roam freely during the investigation process may pose severe threat to the process itself. There is every possibility of the accused fleeing from justice, tampering evidence, influencing or undermining prosecution witness, among other such threats ${ }^{68}$. These threats subsist despite the Court of Sessions or the High Court's power to cancel an order of anticipatory bail under section 439(2), because at times it may get too late to even exercise such a right.

In this scenario, it would have been helpful if the Court had considered and accepted the recommendation of the Amicus Curiae Advocate Harin P. Raval. According to Mr. Raval, in cases where a FIR or a complaint has been filed, an order for anticipatory bail should be limited to a period of 10 days out of the maximum period of 14 days available for police remand under section 167 of the CrPC. This way, it would leave 4 days, out of the total period of 14 days, for police investigation ${ }^{69}$. Granting anticipatory bail till the end of the trial dispossesses the investigating agencies of their right to investigate the accused in custody. Merely joining the course of investigation while on an anticipatory bail cannot be replaced with an investigation in custody in cases where such custody may be rightly required ${ }^{70}$.

63 Sushila Aggarwal v State (NCT of Delhi) SLP (Crl.) Nos. 7281-7282/2017, p. 127 [1(1)].

64 Salauddin para 2

65 Sudesh Kumar Sharma, 'Dimensions of Judicial Discretion in Bail Matters' (1980) 22(3) Journal of Indian Law Institute $351,363$.

66 (1961) 1 SCR 14.

67 Sushila Aggarwal v State (NCT of Delhi) SLP (Crl.) Nos. 7281-7282/2017, p. 130 [1(7) \& (8)].

68 Sudesh Kumar Sharma, 'Dimensions of Judicial Discretion in Bail Matters' (1980) 22(3) Journal of Indian Law Institute 351, 367.

69 Sushila Aggarwal v State (NCT of Delhi) SLP (Crl.) Nos. 7281-7282/2017, p. 12 [3].

70 Sudesh Kumar Sharma, 'Dimensions of Judicial Discretion in Bail Matters' (1980) 22(3) Journal of Indian Law Institute $351,367 \& 369$. 
It was also held in Muraleedharan $v$ State of Kerala that custodial interrogation is of utmost importance and becomes indispensable to unearth all the links between the accused and the crime ${ }^{71}$. Thus, anticipatory bail should not be used as a weapon to "defeat, thwart, stall" and render useless the remand proceedings under the Code for purposes of investigation or to secure incriminating material under section 27 of the Indian Evidence Act $1872^{72}$. As correctly pointed out by Amicus Curiae Harin P. Raval in his submissions, restricting the operation of anticipatory bail would serve the dual purpose by balancing two conflicting interests, namely the personal liberty of the individual and the sovereign investigating power of the police ${ }^{73}$.

Another crucial point in the present case relates to the imposition or non-imposition of any condition in the anticipatory bail order. The court observed that as granting anticipatory bail or refusing it is a matter of discretion of the court, similarly, imposing or non-imposition of conditions on anticipatory bail order is the discretion of the court ${ }^{74}$. The Court is completely justified in imposing any condition other than the ones mentioned in section 438(2), as it may deem fit, based on the facts and circumstances of each case. There is no obligation on the court to impose any special conditions that are not mentioned in section 438 (2) with respect to time, relief etc. as a matter of routine ${ }^{75}$.

Considering the grant of such wide discretion on the concerned courts both by the Code and the SC, it would have been better if such power was restricted in its application to exceptional cases alone. Restricted exercise of power to grant anticipatory bail only in exceptional cases was also recognised by the Law Commission in its 48th Report ${ }^{76}$ as well as by the Punjab and Haryana High Court in the Gurbaksh Singh Sibbia case ${ }^{77}$. The possibility of misuse of such a provision requires certain restrictions to be placed in its operation and function.

At the time of the discussion on its introduction, such misuse was not unknown. As a participant in a debate on the Code of Criminal Procedure Bill, Member of Parliament Bhogendra Jha recognised the possibility of misuse of the provision for anticipatory bail order and criticised the introduction of section 438 in the Code. According to him, with the introduction of section 438, the House was going to do something that even the British Colonial government did not do, i.e. give shield to the capitalists, profiteers and thief-businessmen ${ }^{78}$. He further observed that the provision would give an opportunity to thief-businessmen, usurers and those enjoying on the hard work of others to get anticipatory bail before even getting arrested. According to him, the House would commit a crime by enacting the provision of anticipatory bail ${ }^{79}$ and a reconsideration on its inclusion in the Code. He eventually suggested that if at all such a provision was necessary, then exceptions needed to be carved out for the offence of murder and economic crimes in which case no anticipatory bail would be granted ${ }^{80}$.

1 (2001) 4 SCC 638 [7].

72 Sudesh Kumar Sharma, 'Dimensions of Judicial Discretion in Bail Matters' (1980) 22(3) Journal of Indian Law Institute $351,367 \& 369$.

73 Sushila Aggarwal v State (NCT of Delhi) SLP (Crl.) Nos. 7281-7282/2017, p. 11 [2].

74 Sushila Aggarwal $v$ State (NCT of Delhi) SLP (Crl.) Nos. 7281-7282/2017, p. 129 [1(4)].

75 Sushila Aggarwal v State (NCT of Delhi) SLP (Crl.) Nos. 7281-7282/2017, p. 128 [1(3)].

76 Law Commission, Some Questions under the Code Of Criminal Procedure Bill, 1970 (Law Com Report No 48, 1972).

771977 SCC OnLine P\&H 157, p. 147 [64(1)].

78 Lok Sabha Deb (Seventh Session) 9 May 1973, vol XXVIII, col 276 (Translation by Authors).

79 Lok Sabha Deb (Seventh Session) 9 May 1973, vol XXVIII, cols 276-277 (Translation by Authors).

80 Lok Sabha Deb (Seventh Session) 9 May 1973, vol XXVIII, col 277 (Translation by Authors). 
Similarly, Member of Parliament Ram Ratan Sharma raised concern over the new clause section 438 (anticipatory bail) and observed that it would not benefit the poor. He also observed that all "black-marketeers", "hoarders" or powerful persons who commit serious offences and rich persons would take anticipatory bail and the poor persons for whose benefit the clause was introduced, would never get any benefit. Therefore, he requested the removal of the clause ${ }^{81}$.

\section{Conclusion}

The SC in Sushila Aggarwal should be commended for putting an end to the long-standing ambiguity created by the earlier decisions of the SC on the law relating to anticipatory bail in India. The Court discussed varying judgments of the SC on anticipatory bail and laid to rest uncertainties pertaining to the duration of the order of anticipatory bail. It settled the law on the subject to be followed in subsequent cases and by all courts, devoid of any ambiguity on the matter.

While its efforts should be appreciated on observations relating to non-grant of blanket anticipatory order and information to the Public Prosecutor even at the interim stage, the Court, however, missed the point on some important issues on anticipatory bail law. By allowing an anticipatory bail order to ordinarily operate till the end of the trial, the SC failed to do justice to the very basic foundation and purpose of section 438 as laid down by the Law Commission in its $41^{\text {st }}$ Report. It also failed to recognise the difficulties that an anticipatory bail order operating till the end of the trial would pose on the operation of certain other provisions of the Code such as section 209(b) or the police's power to investigate.

With its interpretation, the SC wrongly placed an anticipatory bail order at the same pedestal as an ordinary bail order without giving regard to the stage at which they are granted. By limiting the duration of an anticipatory bail order, the court could have easily dealt with the problem so created. In such a bail system that mostly operates in favour of the rich and the influential, certain guidelines with respect to time limit and imposition of conditions would have gone a long way in curbing the misuse and abuse of this important provision. This extended anticipatory bail till the end of the trial should rather have been treated as a blanket order, vague and unjust, requiring an imposition of time limit on the same. The law laid down by the SC in Salauddin Shaikh, K.L. Verma and the like seem to be more appropriate on the matter.

This was an opportunity for the Constitution Bench of the SC to fill in the loopholes that were left in the earlier judgment on the subject matter. Instead, it decided to follow its judgment in the Sibbia case and reiterate the view already laid down in that judgment. As a consequence, the SC missed out on a critical opportunity to make the law on the anticipatory bail complete.

81 Lok Sabha Deb (Eighth Session) 3 September 1973, vol XXXI, cols 48-49 (Translation by Authors). 


\section{References}

Amir Chand v Crown ILR (1949) 1 P\&H 515.

Balchand Jain v State of M.P. (1976) 4 SCC 572.

Bhadresh Bipinbhai Sheth v State of Gujarat 20161 SCC 152.

Bharat Chaudhary v State of Bihar (2003) 8 SCC 77.

Black's Law Dictionary 3rd edn., 1933.

Code of Criminal Procedure of India 1973.

Emperor v. H.L. Hutchinson and Another 1931 SCC OnLine All 14.

Emperor v. Joglekar 1931 SCC OnLine All 60.

Gurbaksh Singh Sibbia v State of Punjab 1977 SCC OnLine P\&H 157.

Gurbaksh Singh Sibbia v State of Punjab (1980) 2 SCC 565.

HDFC Bank Limited v J.J. Mannan (2010) 1 SCC 679.

Jubar Mal v State 1954 SCC OnLine Raj 24.

Kelkar RV, Criminal Procedure (6th ed., Eastern Book Company 2014).

K.L. Verma v State (1998) 9 SCC 348.

King Emperor v Khwaja Nazir Ahmad 1944 SCC OnLine PC 29.

Law Commission, The Code of Criminal Procedure 1898 (Law Com Report No 41, 1969).

Law Commission, Some Questions under the Code Of Criminal Procedure Bill, 1970 (Law Com Report No 48, 1972).

Law Commission, The Code of Criminal Procedure 1898 (Law Com Report No 41, 1969). Lok Sabha Deb (Seventh Session) 9 May 1973, vol XXVIII (Translation by Authors).

Lok Sabha Deb (Eighth Session) 3 September 1973, vol XXXI (Translation by Authors). Law Commission, Some Questions under the Code Of Criminal Procedure Bill, 1970 (Law Com Report No 48, 1972).

Madhya Pradesh v Narayan Prasad Jaiswal 1963 SCC OnLine MP 9.

Muraleedharan v State of Kerala (2001) 4 SCC 638.

Nagendra Nath Chakravarti, In Re 1923 SCC OnLine Cal 318.

Nirmal Jeet Kaur v State of MP (2004) 7 SCC 558.

Reserve Bank of India v Peerless General Finance and Investment Co. Ltd (1987) 1 SCC 424.

Salauddin Abdulsamad Shaikh v State of Maharashtra (1996) 1 SCC 667.

Satpal Singh v State of Punjab (2018) 13 SCC 813.

Sharma, SK 'Dimensions of Judicial Discretion in Bail Matters' (1980) 22(3) Journal of Indian Law Institute 351. 
SS Mhetre v State of Maharashtra (2011) 1 SCC 694.

State of UP v Deoman Upadhyay (1961) 1 SCR 14.

Sunita Devi v State of Bihar (2005) 1 SCC 608.

Sushila Aggarwal v State (NCT of Delhi) SLP (Crl.) Nos. 7281-7282/2017.

Uday Mohanlal Acharya v State of Maharashtra (2001) 5 SCC 453. 